\title{
CONTAGION AFFECTS ON AUTOMOBILE SECTOR IN INDIA
}

\section{KRISHNA REDDY ${ }^{1} \&$ P V. VIJAY KUMAR REDDY ${ }^{2}$}

${ }^{I}$ Research Scholar, K L Business School, K L deemed to be University, KLEF, Guntur, Andhra Pradesh, India

${ }^{2}$ Assistant Professor, KL Business School, K L deemed to be University, KLEF, Guntur, Andhra Pradesh, India

\section{ABSTRACT}

India is a country with all types of religions,culture, customs.etc, but the outbreak of corona virus have paved way to a deadly downfall of humans irrespective of age,caste,gender,etc. It also blew the economic growth and industries globally. The ground breaking catastrophe has unchained the world-wide trauma and posed the biggest threat to the global economy. The most crashed businesses are the travel and tourism, consumer goods, automobile, IT, and Insurance.There would be once this crisis situation passes and the companies who survive would emerge stronger in the context of the Indian Automobile Industry,

KEYWORDS: Ground Breaking Catastrophe, Outbreak of Corona Virus, Indian Automobile Industry, Covid-19 \& Pandemic Crisis

Received: May 09, 2020; Accepted: May 29, 2020; Published: Jul 28, 2020; Paper Id.: IJMPERDJUN2020492

\section{INTRODUCTION}

India is a country with all types of religions, culture,customs.etc, but the outbreak of coronavirus have paved way to a deadly downfall of humans irrespective of age,caste,gender,etc.It also blew the economic growth and industries globally. The groundbreaking catastrophe has unchained the world-wide trauma and posed the biggest threat to the global economy. The most crashed businesses are the travel and tourism, consumer goods, automobile, IT, and Insurance.

In accordance to the review of McKinsey\&Company claims that the US and EUROZONE'S economies would take until 2023 to recoup from the impact of the crisisin an optimistic scenario with a mean global GDP drop of 4.7 percent. (R2) 


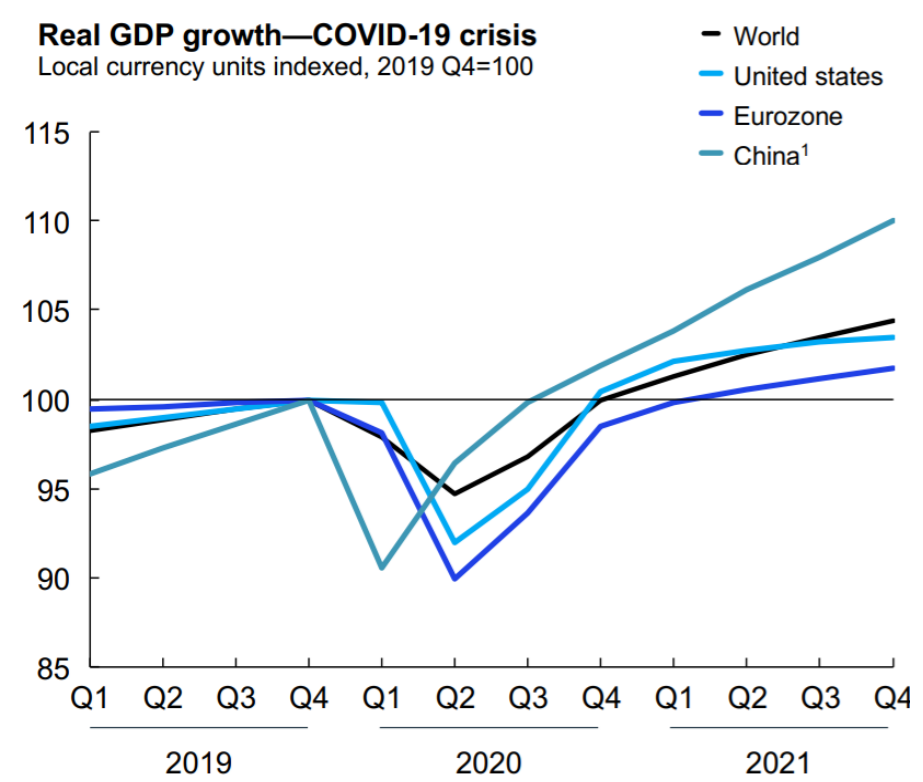

Most countries are expected to experience sharp decline in Q2 which would be un precedent in the post WWII era.

\begin{tabular}{|c|c|c|c|}
\hline & $\begin{array}{c}\text { Real GDP drop } \\
2019 \\
\text { Q4-2020 Q2 \% } \\
\text { Change }\end{array}$ & $\begin{array}{l}2020 \text { GDP } \\
\text { growth } \\
\% \text { Change }\end{array}$ & $\begin{array}{l}\text { Time to return to pre } \\
\text { crisis Quarter }\end{array}$ \\
\hline Chaina & $-4.2 \%$ & $-2.3 \%$ & $2021 \mathrm{Q} 2$ \\
\hline USA & $-11.1 \%$ & $-8.7 \%$ & $2024 \mathrm{Q} 2$ \\
\hline World & $-7.2 \%$ & $-5.7 \%$ & $2022 \mathrm{Q} 4$ \\
\hline Euro Zone & $-13.2 \%$ & $-10.6 \%$ & $2024 \mathrm{Q} 4$ \\
\hline
\end{tabular}

Source: McKinsey Analysis in partnership with Oxford Economics.

If the inhabitants health reaction, including social distancing and lockdown measures, are initially successful, but failed to prevent the re-emergence of the virus, the world will experience a "muted" economic recovery, says McKinsey.During this situation, while the world-wide economy would recover to the pre-crisis levels by the third quarter of 2022.

The US economy would wish until the primary quarter of 2023, and Europe till the third quarter of an equivalent year. The sectors that have to take the major impact of this contagion are the travel, tourism, commodity, hotel, hospitality, automotive and financial markets. The accurate consequences of this pandemic would be clearly known in the coming weeks once countries start to retrieve from this crisis.

\section{Automotive Industry Global Economic Trade Impact of Covid 19 Pandemic}

According to Meticulous Research ${ }^{\circledR}$ estimate that the current COVID-19 crisis will severly affect the global automotive industry resulting in a 12\%-15\% dip in market in 2020 and new car registrations in big 5 European car markets. New car registration in big 5 European markets have taken a hit with Germany, Italy, Spain, UK, and France reporting a decline.( R6\&R8)

Table 1

\begin{tabular}{|l|c|}
\hline Country & $\begin{array}{c}\text { New Car } \\
\text { Registration }\end{array}$ \\
\hline Germany & $11 \%$ \\
\hline
\end{tabular}




\section{Source: Meticulous Research report dated}

\begin{tabular}{|l|l|} 
Italy & $9 \%$ \\
\hline Spain & $6 \%$ \\
\hline UK & $3 \%$ \\
\hline France & $3 \%$ \\
\hline
\end{tabular}

\section{Graph 1}

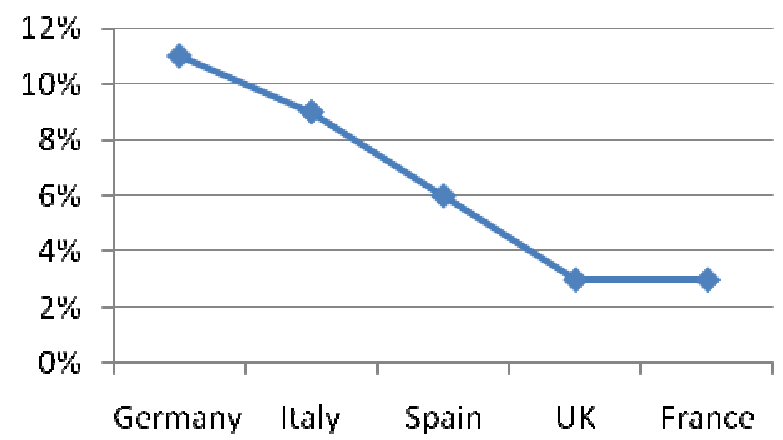

New car registration in big 5 European markets decline $(\downarrow)$

We are surrounded by worldwide pandemic which has been hitting every product and segment of all the global automakers have been hit. In that scenario most of their subsidiaries in India would have to fend on their own with virtually no help of guidance from their parents, who themselves are facing a bigger crisis The current auto OEM status (R1) is given below.

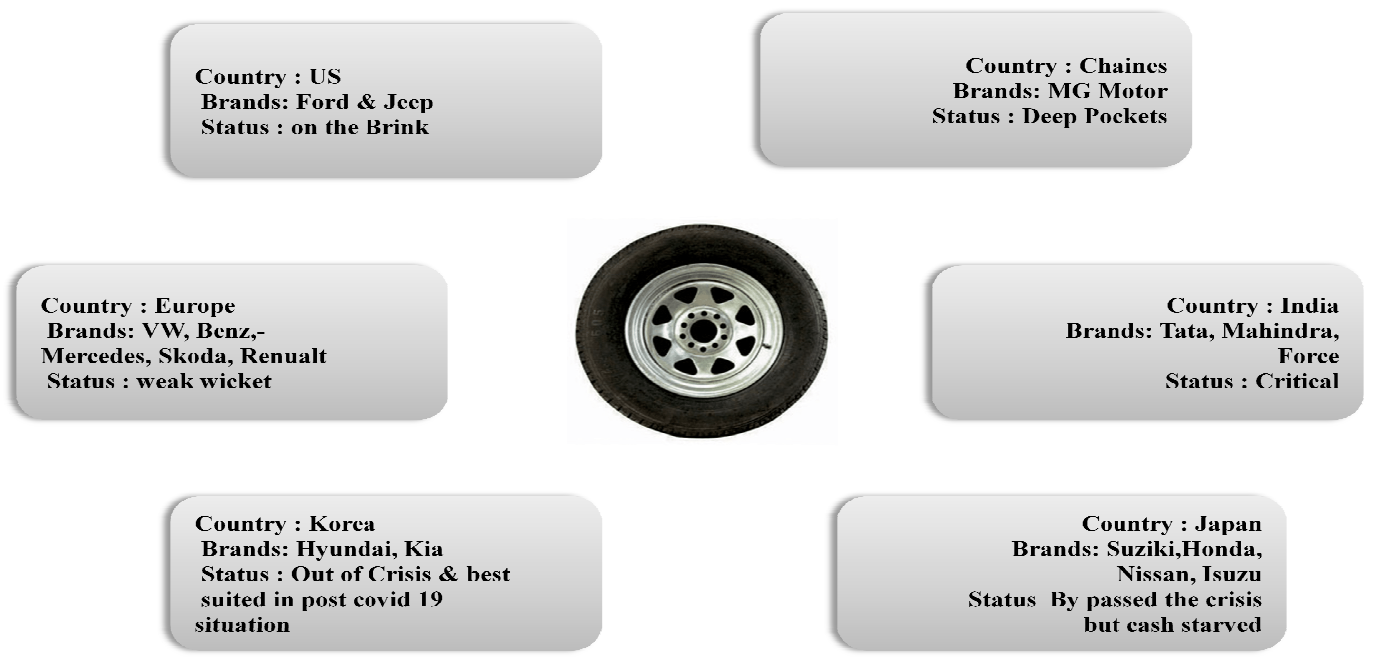

Figure 1

Countrywise Auo OEM Status Report

Source : www.ET auto.com

\section{IMPACT ON THE INDIAN AUTOMOBILE INDUSTRY}

According to the SIAM,India would be the world's fourth - largest passenger vehicle market by 2021.For India it took around seven years to expand its annual production to four millions vehicles from three million.However, the subsequent milestone-five million-is envisaged in less than five years. The automotive industry established a prolonged supply chain. 
It has to source an enormous amount of materials varying from ferrous metals to non-ferrous metals, plastics, and electronics.the supply chain must be robust to ensure seamless production on a regular basis. Most of the vehicle producers have either own bases for the supply of materials or have suppliers based on China.these have been seriously affected by the COVID-19 catastrophe(R3\&R4).

As supply chains around the world are suspended, the full impact is yet to be felt. Business leaders must work up for the effects on production, transport, and logistics, and customer demand. These include a plungeinurge from consumers lead the way to inventory "whiplash," as well as parts and labour shortages due to manufacturing plants shutting or reducing capacity.

The International Monetary Fund (IMF) further slashed India's growth estimate for FY21 to $1.9 \%$ from $5.8 \%$ estimated in January, warning that the "worst recession since the Great Depression" will dwarf the economic damage caused by the global financial crisis a decade back. It also said that India and China would be the only two major economies likely to register growth, with all others contracting. (R18)

The auto companies, OEMs will begin production from mid of May onwards [if the lowdown is lifted], and expected mean price drop of one percent over all fragments, supply chain disrupted across the entire industry, however, a full-fledged industry like cars revs up quickly, the business are going to be fully production level from June 2020 onwards.(R5\&R6)

According to Rajesh Menon, director general, SIAM, Automobile industry continues to face hardship due to steeper decline in production and wholesale dispatches in all segments in february 2020,” (R17)

In slow lane

Note: Domestic sales only

\begin{tabular}{|l|c|c|c|}
\hline \multicolumn{1}{|c|}{ Category } & Feb-19 & Feb-20 & \% Chgî \\
\hline Passenger Vehicles & 272,243 & 251,516 & -7.61 \\
\hline Commercial Vehicles & 87,436 & 58,670 & -32.9 \\
\hline Three - wheelers & 59,875 & 41,300 & -41.02 \\
\hline Two wheelers & $1,614,941$ & $1,294,791$ & -19.82 \\
\hline \multicolumn{1}{|c|}{ Overall } & $\mathbf{2 , 0 3 4 , 4 9 5}$ & $\mathbf{1 , 6 4 6 , 2 7 7}$ & $\mathbf{- 1 9 . 0 8}$ \\
\hline
\end{tabular}

Source: Society of Indian Automobile Manufacturers

Key original equipment manufactures (OEMs) including Tata Motors, KIA, Mahindra, Volkswagen, Renault, Hyundai, Maruti, Ford, Toyota, Volvo, FCA, MG Motors, are trying their best to give safe working environment to factory workers and other employees in key operational roles in order to ensure that supply chain does not get 'further' impacted and major comapnes are shut down their plats.

Volvo Car India announced a 'work from home' strategy as a safety measure with immediate effect. As part of its overall health and safety plan to mitigate risks associated with Covid-19, the company said the "the necessary IT infrastructure is in place to facilitate business continuity, with scheduled meetings managed via Microsoft Teams/ Skype."(R13)

Mahindra \& Mahindra announced a 'work from home' (WFH) policy, from March 18-31, for 7,000 desk-based staffers. However, the company's manufacturing and R\&D operations will continue functioning (R14) 
Fiat Chrysler Automobiles (FCA) India which retails the Jeep brand of SUVs, says it "has permitted over 50\% of its staff in its Mumbai and Pune offices to work from home, at least until March 31, 2020, and is taking proactive measures to ensure 'social distancing', which is the need of the hour. (R15)

General Motors announced that it suspended operations at its Talegaon plant since March 21 in the wake of the COVID19 outbreak in India. (R16)

Toyota Kirloskar Motor temporarily shut down its production plant in Bidadi, (R19)Karnataka on Sunday, March 22. In light of the recent directions given by the Government of Karnataka, the plant will continue to remain shut until further notice. TKM has extended the 'Work From Home' policy to all its employees at its corporate office in Bidadi, along with its regional SBUs (Strategic Business Units) in Delhi, Mumbai, Kolkata and Bengaluru.

Volkswagen India has also announced relief for customers on the service and warranty front. Standard warranties expiring between March 22 and mid-May will now be valid till July 31, 2020

Kia Motors India has announced that, with immediate effect, it will be temporarily shutting down all operations, till further notice. This include Kia's offices and manufacturing facility in Anantapur (Andhra Pradesh). Kia's digital channels will, however, remain open for customers.(R14)

\section{THE SUPPLY DISRUPTION IN CHINA}

China accounts for about 27 percent of India's automotive part imports and major global auto part makers such as Robert Bosh GmbH, Valvo AS and ZF Friedrichshafen AG have factories located in the Hubei province. Owing to the closure of the factories of these companies, there has been a delay in the production and delivery of vehicles like Bharat Stage Four(BS-IV) complaint models.

Post COVID-19 related lockdown from China, demand resurfaced swiftly indicating signs of a V- shaped recovery. OEMs expect domestic PV sales to recover by the festive season of CY20. JM financial says despite the ongoing slowdown in economic activity arising from the COVID-19, the medium-term outlook for tractor sales remains positive, driven by strong Rabi output, good reservoir levels and expectation of normal monsoon in CY20. It is said the tractor industry will recover ahead of PVs, followed by $2 \mathrm{Ws}$.

\section{BS VI TRANSMISSION IMPACT}

In case of PVs, OEMs like MSIL, Hyundai, and Toyota outperformed its peers, driven by early shift to BSVI and low BSVI inventory. While MSIL dispatched c.77,000 units in the domestic market with sales declining 48\% YOY, sales of Toyota /Hyundai declined 45\%/41\%, respectively. In 2WS, OEMs faced issues over exciting BSVI inventory with the dealers, which was exacerbated by COVID-19 related lockdown and a limited relief from SC on sale of BSVI inventory.(R11)

According to a report released by the Fitch Solutions, vehicle production in India is likely to contract by 8.3 percent in 2020 following an estimated 13.2 per cent decline in 2019. Covid-19 will also make the transition to BSVI emission norms difficult.(R1) 


\section{NEAR -TERM OUTLOOK FOR THE AUTO SECTOR}

HDFC securities says the auto industry in India is envisioned to behold multiple disruptions, from mobility services and electrical vehicles in the medium term(R12). It is said EVs are at the startup stage of the s-curve, while shared mobility is in the growing stage. However, sustained profitability is crucial to make sure scale and longevity of operations and business models will continue to evolve on the road map to beneficial growth.

The growth is now arising from $2 \mathrm{~W}$-based operators as the traditional cab-based aggregators (Ola, Uber) are unable to extend beyond the large metros. Start-ups such as Bounce, Vogo, Yulu are focusing on the bike rental model while rapido has adopted the bike aggregation model The latter segment is growing exponentially (of a low base) with a current market size of $\$ 150 \mathrm{mn}$. These services are expanding over tier-I and tier-II towns due to the economical fares/improved connectivity. (R9)

The Reserve Bank of India announced of tranche of Liquidity boost for the economy with 25 base points reverse repocut.the move has been taken to allow bank to lend more. These liquidity measures are over and above the 3074n Lakhs liquidity boost in the last week of March 2020. (R20)

\section{TAKEOFF OF ELECTRIC VEHICLES}

There has been a gush of electric vehicles development activity post the FAME-II scheme( R9). 2W OEMs have launched premium scooters (Ather 450x, Bajaj chetak, TVS i-Qube), passenger car OEMs have launched high end products and electric buses are being publicized by Chinese and domestic OEMs. Mass adoption of EVs is expected only in the medium term though.

As EV technology evolves and ride sharing services make inroads into tier-II cities, the growth rates for 2wheelers will be impacted on the medium term. Industry growth has already moderated to 6-8\%(versus double digit growth earlier) as penetration levels have exceeded $50 \%$ of household in India. We believe that as a second vehicle usage in households get cannibalized, industry growth rates are likely to moderate to sub 5\% levels.

\section{Electrical Vehicles Sales in India}

\begin{tabular}{|l|l|l|}
\hline Segment & FY2020 & FY2019 \\
\hline Two Wheelers & 152,000 & 126,000 \\
\hline Three Wheelers & NA & 630,000 \\
\hline Passenger Vehicles & 3,400 & 3,600 \\
\hline Buses & 600 & 400 \\
\hline Total & $\mathbf{1 5 6 , 0 0 0}$ & $\mathbf{7 5 9 , 6 0 0}$ \\
\hline
\end{tabular}

\section{Source: www.autocorpo.in( R10)}

\section{Prospects and Reinforcement Strategies}

There is never a one pill solution for any kind of business contingency at any point in time. Extremely unpredictable times like these brought about by the COVID-19 pandemic crisis teaches the values of risk assessment and thereby preparing contingency plans for business. There would be once this crisis situation passes and the companies who survive would emerge stronger in the context of the Indian Automobile Industry. 


\section{CONCLUSIONS}

A prolonged truncation of consumer demand due to the lockdown is seen significantly affecting auto manufacturers (OEMs) revenues and cash flow declares may not deliver vehicles during the lockdown. might be suppliers have a high dependence on migrant Labour. Captive financecompanies are also likely to face the brunt, as loan defaults are likely to shoot-up, and new loans are expected to drop, given difficulties in determining customers' creditworthiness, further denting the firms' profitability. Company should reinvent their plans and marketing techniques, The coronavirus pandemic will bring tough and challenging times for the automobile industry in the current fiscal. A drop of around 40 percent in car sales can be expected

\section{REFERENCES}

1. Economics Times dated April $10^{\text {th }}, 2020$

2. www.McKinsey.com

3. www.yourstory.com

4. KPMG report 'Potential Impact of COVID-19 on Indian economy' estimates

5. www.business-standard.com

6. Source: Meticulous Market Research Pvt. Ltd. May 11, 2020 09:30

7. www.vynzresearch.com/automotive-transportation/covid-19-outbreak-automotive-industry

8. Globe Newswire, New York, May 15, 2020

9. Economictimes.indiatimes.com/industry/auto/auto-news/govts-rs-10000-cr-scheme-to-promote-electric-vehicles

10. www.autocarpro.in/news-national

11. www.autocarindia.com/ dated $16^{\text {th }}$ may 2020

12. www.hdfcsec.com

13. https://www.outlookindia.com/newsscroll/volvo-car-india-asks-all-employees-to-work-from-home/1767925

14. https://economictimes.indiatimes.com/industry/auto/auto-news/kia-motors-india-temporarily-suspends-operations-atanantpur-plant/articleshow/74774914.

15. https://www.livemint.com/news/india/coronavirus-fca-india-asks-over-50-of-staff-to-work-from-home-11584450335610.html

16. https://www.businesstoday.in/current/corporate/coronavirus-outbreak-general-motors-suspends-production-at-maharashtraunit-till-march-31/story/399016.html

17. Society of Indian Automobile Manufacturers

18. International Monetary Fund report dated April $13^{\text {th }} 2020 /$

19. https://economictimes.indiatimes.com/news/economy/indicators/imf-projects-indias-growth-rate-at-1-9-in-2020-forecastsglobal-recession-due-to-covid-19/articles

20. https://www.thehindubusinessline.com/economy/logistics/toyota-halts-production-at-bidadi-plants/article31140200.ece

21. Reserve Bank of India announcements. $\underline{\text { www.rbi.org.in }}$ 
22. Almusaddar, Ayman AS, Sara RavanRamzan, and Valliappan Raju. "The Influence of Knowledge, Satisfaction, and Motivation on Employee Performance Through Competence." International Journal of Business and General Management (IJBGM) 7.5 (2018): 21-40.

23. RANI, POONAM, and VEERPAUL KAURMANN. "CONTAGION EFFECT OF MACRO ECONOMIC VARIABLES ON IPO LISTING ACTIVITY: A TIME SERIES ANALYSIS IN INDIAN CONTEXT."International Journal of Business Management \& Research (IJBMR) 7. 4, Aug 2017, 47-52 